\title{
Capturing metal-support interactions in situ during the reduction of a Re promoted Co/-Al2O3 catalyst
}

Tsakoumis, N. E.; Johnsen, Rune E.; van Beek, W.; Rønning, M.; Rytter, E.; . Holmen, A.

Published in:

Chemical Communications

Link to article, DOI:

$10.1039 / \mathrm{c} 5 \mathrm{cc} 09879 \mathrm{c}$

Publication date:

2016

Document Version

Peer reviewed version

Link back to DTU Orbit

Citation (APA):

Tsakoumis, N. E., Johnsen, R. E., van Beek, W., Rønning, M., Rytter, E., \& . Holmen, A. (2016). Capturing metal-support interactions in situ during the reduction of a Re promoted $\mathrm{Co} /-\mathrm{Al}_{2} \mathrm{O}_{3}$ catalyst. Chemical
Communications, 52(15), 3239-3242. https://doi.org/10.1039/c5cc09879c

\section{General rights}

Copyright and moral rights for the publications made accessible in the public portal are retained by the authors and/or other copyright owners and it is a condition of accessing publications that users recognise and abide by the legal requirements associated with these rights.

- Users may download and print one copy of any publication from the public portal for the purpose of private study or research.

- You may not further distribute the material or use it for any profit-making activity or commercial gain

- You may freely distribute the URL identifying the publication in the public portal 


\section{Journal Name}

\section{COMMUNICATION}

\section{Capturing metal-support interactions in situ during the reduction of a Re promoted $\mathrm{Co} / \mathrm{Y}-\mathrm{Al}_{2} \mathrm{O}_{3}$ catalyst.}

Received 00th January 20xx, Accepted 00th January 20xx

DOI: $10.1039 / x 0 x \times 00000 x$

\author{
N. E. Tsakoumis, ${ }^{* a}$ R. E. Johnsen, ${ }^{b}$ W. van Beek, ${ }^{c}$ M. Rønning, ${ }^{a}$ E. Rytter, ${ }^{a, d}$ and A. Holmen ${ }^{a}$
}

www.rsc.org/

The reduction of a $\mathrm{Re}$ promoted $\mathrm{Co} / \mathrm{v}-\mathrm{Al}_{2} \mathrm{O}_{3}$ catalyst was monitored in situ by synchrotron X-ray powder diffraction (XRPD) under $\mathrm{H}_{2}$ environment. Whole powder pattern analysis showed a non-linear expansion of the unit cell of $\mathrm{V}-\mathrm{Al}_{2} \mathrm{O}_{3}$ during the reduction process suggesting the diffusion of cobalt cations into the structure of the $\mathrm{V}-\mathrm{Al}_{2} \mathrm{O}_{3}$ support material. The cell expansion coincided with the formation of $\mathrm{CoO}$ phase. Evidence for the negative effect of the partial pressure of indigenous $\mathrm{H}_{2} \mathrm{O}$ on the reduction process was obtained by alternating XRPD probing of the inlet and outlet ends of the reactor.

Catalyst activation is a critical step of the start-up procedure for most industrial catalytic processes. ${ }^{1}$ Commonly a solid precursor is been subjected to specific conditions that allow transformation to the catalytically active component, ex situ or in situ. In many catalytic applications, the metallic surface of nanoparticles is the active component and therefore reduction of supported metal oxide precursors precedes. The reduction process is affected by various parameters such as the nature of the precursor, the size of the nanoparticles, the reactivity of the support, the reducing atmosphere. The execution of the activation step has an impact on catalyst structure and performance, avoiding risks of sintering or a lower final degree of reduction. ${ }^{2}$ In the last decades, in situ investigations have boosted catalysis research and allowed the deconvolution of such complex phenomena. ${ }^{3}$

Cobalt nanoparticles (NPs) supported on high surface area porous materials such as $\mathrm{\gamma}-\mathrm{Al}_{2} \mathrm{O}_{3}$ are used in various processes. One of the most important industrial applications is the Fischer-

\footnotetext{
a. Department of Chemical Engineering, Norwegian University of Science and Technology (NTNU), NO-7491 Trondheim, Norway.

b. Department of Energy Conversion and Storage, Technical University of Denmark, Roskilde, Denmark.

c. Swiss-Norwegian Beamlines at ESRF, BP 220, Grenoble 38043, France,

d. SINTEF Materials and Chemistry, NO-7465 Trondheim, Norway

+ Footnotes relating to the title and/or authors should appear here.

Electronic Supplementary Information (ESI) available: [details of any

supplementary information available should be included here]. See

DOI: $10.1039 / \mathrm{x} 0 \times x \times 0000 x$
}

Tropsch synthesis (FTS). ${ }^{4}$ FTS is the heart of Gas-to-Liquid (GTL) technologies and a tool for the utilization of synthesis gas derived from different feedstocks i.e. natural gas, coal and biomass. In cobalt based FTS carbon monoxide and hydrogen are converted into a mixture of linear long-chain hydrocarbons while significant amounts of steam are co-produced. The active metallic Co is commonly formed by reduction in $\mathrm{H}_{2}$ of the $\mathrm{CO}_{3} \mathrm{O}_{4}$ spinel precursor produced after drying and calcination of the impregnating source. The activation procedure is important for the optimization of catalysts selectivity ${ }^{5}$ and stability ${ }^{6}$.

The reduction of promoted and un-promoted $\gamma$-alumina supported $\mathrm{Co}_{3} \mathrm{O}_{4}$ NPs has been studied in detail either by conventional temperature programed reduction (TPR) ${ }^{7-9}$ or by advanced in situ techniques including X-ray powder diffraction $(\mathrm{XRPD})^{10}$, X-ray absorption spectroscopy $(\mathrm{XAS})^{11-14}$ and transmission electron microscopy (TEM) ${ }^{15}$. From the majority of the reports, it is evident that the reduction is a two-step process that reaches the polycrystalline metallic Co through a $\mathrm{CoO}$ intermediate. The use of dopants can either promote or impede this reduction process.

$$
\begin{aligned}
& \mathrm{Co}_{3} \mathrm{O}_{4}+\mathrm{H}_{2} \rightarrow 3 \mathrm{CoO}+\mathrm{H}_{2} \mathrm{O} \\
& \mathrm{CoO}+\mathrm{H}_{2} \rightarrow \mathrm{Co}^{0}+\mathrm{H}_{2} \mathrm{O}
\end{aligned}
$$

Although most of the reports agree on the steps of the reduction procedure the formation of mixed compounds of Co with the $\mathrm{\gamma}-\mathrm{Al}_{2} \mathrm{O}_{3}$ support during reduction has been debated. The mixed phase due to its amorphous nature, low concentrations and possible chemical similarities with divalent Co species present in $\mathrm{CoO}$, is difficult to probe. The observed peaks at the high temperature region $\left(>600^{\circ} \mathrm{C}\right)$ of TPR profiles are commonly related to Co species that are difficult to be reduced as a result of strong interaction with the support.

The Co-support interaction has been indirectly detected for catalysts calcined at high temperatures $\left(>500^{\circ} \mathrm{C}\right)$ by the lattice expansion of $\mathrm{Al}_{2} \mathrm{O}_{3}$ as observed by ex situ XRPD performed after calcination ${ }^{16}$. Rutherford backscattering spectrometry (RBS) and X-ray Absorption Near Edge Structure (XANES) studies also 
suggested the formation of such compounds is size sensitive and takes place during catalyst calcination ${ }^{17,18}$.

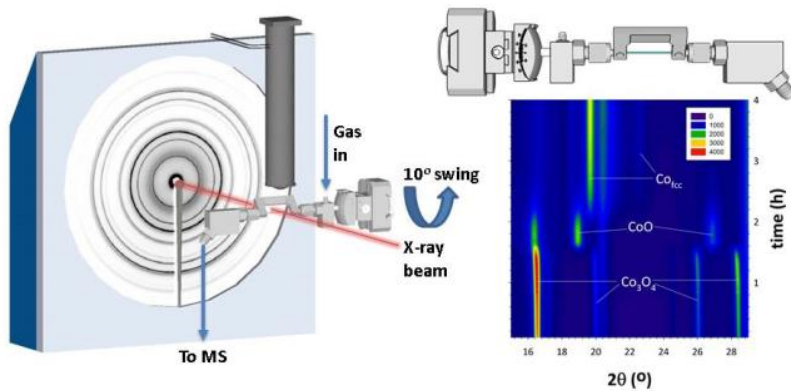

Fig. 1 Representation of the used set-up configuration together with a 3D representation of the in situ cell and a contour plot of the obtained data set showing the main crystalline phases evolving during the course of reduction.

Furthermore detailed TPR and XANES studies pointed on the formation of such a compound during catalyst reduction $7,8,19$. Although (XANES) has been regularly applied for the detection of Co-support mixed compounds $14,20,21$, due to its sensitivity towards oxidation state and local geometry, direct observation on the exact timing of this interaction has not been reported.

In the present study a $\mathrm{Re} / \mathrm{Co} / \mathrm{Y}^{-}-\mathrm{Al}_{2} \mathrm{O}_{3}$ catalyst has been reduced and monitored in situ. Synchrotron XRPD is applied in order to shed light on to the different structural changes that occur during the reduction process. Apart from the crystalline phases that are evolving indirect information on the formation of cobalt-support mixed compounds is obtained by the lattice expansion of the $\mathrm{\gamma}-\mathrm{Al}_{2} \mathrm{O}_{3}$ support.

The catalysts used in this study consist of $20 \mathrm{wt} \%$ cobalt, $1 \mathrm{wt} \%$ rhenium supported on a high surface area $\mathrm{y}-\mathrm{Al}_{2} \mathrm{O}_{3}(186$ $\mathrm{m}^{2} / \mathrm{g}$, Puralox SCCa from Sasol $\left.\mathrm{GmbH}\right)$. The catalyst was prepared by co-impregnation of $\mathrm{Co}\left(\mathrm{NO}_{3}\right)_{2} \cdot 6 \mathrm{H}_{2} \mathrm{O}$ and $\mathrm{HReO}_{4}$. More details on the catalyst preparation and properties can be found elsewhere ${ }^{14}$. In situ XRPD measurements were performed at Stations BM01A and BM01B of the Swiss-Norwegian Beamlines (SNBL) ${ }^{22}$ located at the European Synchrotron Radiation Facility (ESRF) in Grenoble, France. A capillary based in situ cell was used in a set-up configuration similar to that proposed previously ${ }^{23,24}$. The sample was heated by a vertical hot air blower. A swing movement of a few degrees was applied for increased signal statistics. A scheme of the experimental configuration together with the design of the cell and acquired diffraction patterns can be seen in Fig. 1. Powder diffraction images were collected using area detectors at wavelengths of $0.70417 \AA$ (BM01A) and $0.505 \AA$ (BM01B). The obtained images were converted to normal one-dimensional powder patterns using the program FIT2D 25 , which were analysed by the TOPAS v4. $2^{26}$ and Fityk $0.9 .8^{27}$ software packages

The $\mathrm{CO}_{3} \mathrm{O}_{4}$ NPs were reduced by exposing the $\mathrm{Re} / \mathrm{Co} / \mathrm{Y}-\mathrm{Al}_{2} \mathrm{O}_{3}$ catalyst to a pure hydrogen flow of $2.5 \mathrm{ml} / \mathrm{min}$ at ambient pressure, while the temperature was increased from $25{ }^{\circ} \mathrm{C}$ to $400{ }^{\circ} \mathrm{C}$ at a heating rate of $3{ }^{\circ} \mathrm{C} / \mathrm{min}$. The temperature was held at the set-point for 4 hours before returning to ambient conditions. For the TPR-XRPD experiment the heating rate was adjusted to $3^{\circ} \mathrm{C} / \mathrm{min}$ in the temperature range of $100-700^{\circ} \mathrm{C}$
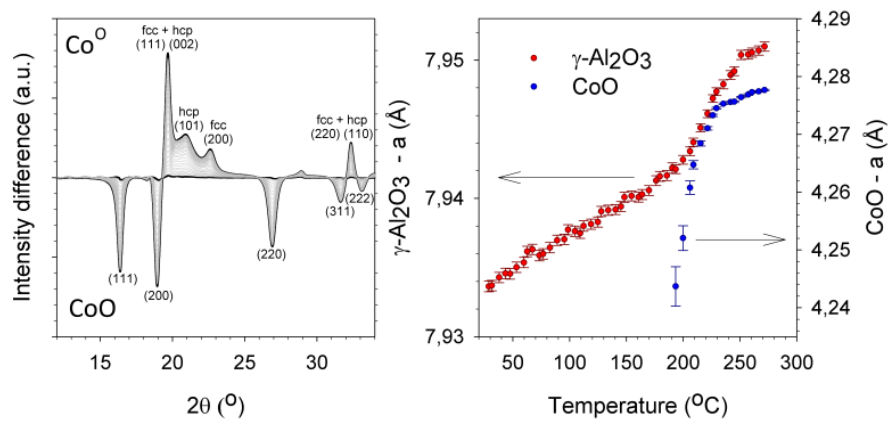

Fig. $2 \mathrm{X}$-ray diffraction patterns from $250^{\circ} \mathrm{C}$ to the reductions end, obtained by the subtraction of the diffractogram with $\mathrm{CoO}$ at maximum intensity (at $250^{\circ} \mathrm{C}$ ), showing the formation of metallic $\mathrm{Co}$ (top half) and disappearance of $\mathrm{CoO}$ (bottom half), (left). Variation in the lattice constant for $\mathrm{y}-\mathrm{Al}_{2} \mathrm{O}_{3}$ and the $\mathrm{CoO}$ as a function of reduction temperature (right).

The diffraction patterns obtained during the course of reduction, clearly demonstrate that phase transformations occur . Initially $\mathrm{CO}_{3} \mathrm{O}_{4} \mathrm{NPs}$ of spinel structure, consisting of a mixture of $\mathrm{Co}^{3+}$ in octahedral environment $\left(\mathrm{O}_{\mathrm{h}}\right)$ and $\mathrm{Co}^{2+}$ in tetrahedrally coordinated positions $\left(\mathrm{T}_{\mathrm{d}}\right)$, are transformed to $\mathrm{CoO}$. $\mathrm{CoO}$ has $\mathrm{Co}^{2+}$ cations octahedrally coordinated and packed in a face-centred cubic (rock salt) type crystal structure. Oxygen is removed from the lattice by generating $\mathrm{H}_{2} \mathrm{O}_{(\mathrm{g})}$. Ultimately metallic Co forms in a convoluted nature containing contributions from both hexagonal closed packed (hcp) and face-centred cubic ( $f(c)$ Co, with the second being more pronounced (Fig. 1). By subtracting the pattern with maximum intensity of the intermediate $\mathrm{CoO}$ phase (obtained at $250{ }^{\circ} \mathrm{C}$ ) from the following patterns the formation of metallic Co can be clearly visualised (Fig. 2). With the exception of the (100) reflection of the hcp Co, that cannot be seen due to overlap with the (200) reflection of the $\mathrm{CoO}$, the peaks are demonstrating the existence of both cubic and hexagonal phases of metallic Co. It also becomes apparent that the phases are growing simultaneously similarly to the reduction of carbon supported Co NPs ${ }^{28}$.

At the examined temperature range and with the applied linear temperature ramping of $3{ }^{\circ} \mathrm{C} / \mathrm{min}$ a linear thermal expansion of the $\gamma-\mathrm{Al}_{2} \mathrm{O}_{3}$ support is expected ${ }^{29}$. Nevertheless, a sudden increase in the unit cell dimensions of $\mathrm{\gamma}-\mathrm{Al}_{2} \mathrm{O}_{3}$ is observed at temperatures exceeding $190{ }^{\circ} \mathrm{C}$. This deviation from linearity comes in addition to the expected thermal effect and coincides with the formation of the $\mathrm{Co}^{2+} \mathrm{O}_{\mathrm{h}}$. That suggests the partial incorporation of $\mathrm{Co}^{2+}$ ions into the $\gamma-\mathrm{Al}_{2} \mathrm{O}_{3}$ lattice stabilizing its disordered structure. Extrapolation of the linear part at a certain temperature and its comparison with the observed value at the same temperature reveals a $0.064 \%$ increase in the lattice constant and an expansion of the unit cell volume equal to $0.19 \%$. By taking into account the concentration of $\mathrm{Co}$, the size of $\mathrm{CoO}$ crystallites and with the assumption of hemispherical particles the interface of the $\mathrm{CoO}$ NPs and support is estimated to be less than $2 \%$ of the total available surface area of the $\mathrm{\gamma}-\mathrm{Al}_{2} \mathrm{O}_{3}$. 

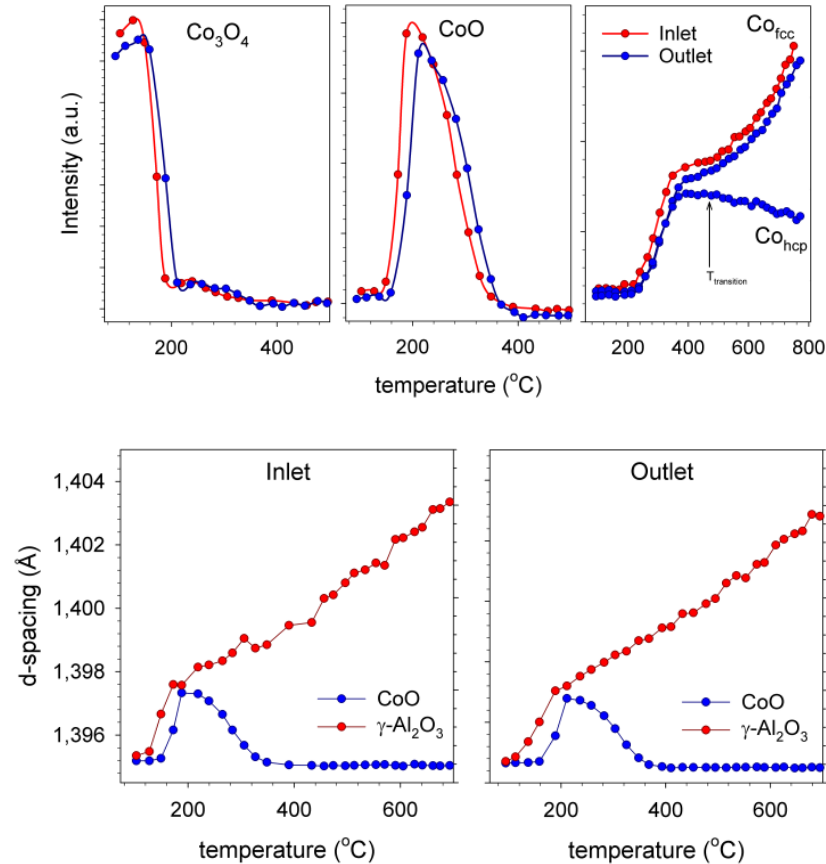

Fig. 4 Peak Intensities of selected reflections for $\mathrm{CO}_{3} \mathrm{O}_{4}(220), \mathrm{CoO}(220)$ and fcc-Co (200) in the inlet and outlet of the reactor (top). The d-spacing of (440) reflection of $\mathrm{Y}$ $\mathrm{Al}_{2} \mathrm{O}_{3}$ plotted together with the maximum intensity of $\mathrm{CoO}$ (bottom).

From the above it becomes apparent that the observed expansion is significant considering the small number of lattice entry points of the $\mathrm{Co}^{2+}$ due to the minor interfacial area. In contrast no bulk $\mathrm{CoAl}_{2} \mathrm{O}_{4}$ could be detected suggesting that the interacting domains lack long-range order. Thus it becomes apparent that the majority of the interfacial area contributes to the phenomenon, while the diffusion of $\mathrm{Co}^{2+}$ cations is probably limited to sub-surface layers of $\gamma-\mathrm{Al}_{2} \mathrm{O}_{3}$. The solid-state reactions of $y-\mathrm{Al}_{2} \mathrm{O}_{3}$ with transition metal cations of low valence has been early identified to proceed through the counterdiffusion of metal in divalent state and $\mathrm{Al}^{3+}$ ions, yet at much higher temperatures ${ }^{30}$. Here although the examined temperatures are low the partial penetration of $\mathrm{Co}^{2+}$ cations is observed and detected as expansion in the unit cell of $y-\mathrm{Al}_{2} \mathrm{O}_{3}$ support. One could speculate that entry points are octahedral $\mathrm{Al}^{3+}$ vacancies explaining the fact that XANES cannot probe and distinguish the structure from the octahedrally coordinated $\mathrm{Co}^{2+}$ cations in the $\mathrm{CoO}$ phase.

For the TPR-XRPD experiment (SNBL, station BM01B) the reactos profile was analysed during catalyst reduction. For this reason the X-ray beam was divided into two parts and the inlet and outlet were probed sequentially. The results are presented in Fig. 4. It becomes apparent that diffusion of $\mathrm{Co}^{2+}$ cations occurs in the full length of the reactor during the reduction process. It is also observed that the phenomenon is irreversible, even at temperatures as high as $700^{\circ} \mathrm{C}$. Besides the reactors outlet exhibits a delay on the reduction process. The delay concerns both reduction steps. The $\mathrm{CoO}$ intermediate reaches its maximum approximately $20{ }^{\circ} \mathrm{C}$ higher than the observed temperature for the inlet. The evolution of both fcc and hcp Co phases are equally delayed. Furthermore, phase transition of metallic Co, although not well resolved in the current dataset, it appears to occur at temperatures higher than $450{ }^{\circ} \mathrm{C}$, a temperature higher than the Co transition of the bulk or Co NPs supported on the less interacting carbon 28 and $\beta$-SiC 31 structures. This delay in transition temperature can be an indirect effect of the developed metal-support interactions.

Here it should be noted that in the particular experiment the temperature is extracted from the probed area. Thus possible temperature gradient of the reactor is eliminated ${ }^{14}$. More specifically the $(400)$ reflection of the hexagonal boron nitride (h-BN) internal standard was followed in the diffraction patterns and temperature was calculated by using the thermal expansion coefficient of the c-axis ${ }^{32}$.

$c=6.6515(\AA)+2.74 \cdot 10^{-4} T(\AA / \mathrm{K})$

Since the process is temperature normalized the only difference between the start and end of thereduction is the chemical environment. In particular the ratio of partial pressures of $\mathrm{H}_{2}$ $\left(\mathrm{pH}_{2}\right)$ and the in situ generated water $\left(\mathrm{pH}_{2} \mathrm{O}\right)$ is changing throughout the length of the reactor. Although the applied gas hourly space velocities are high and consequently the $\mathrm{pH}_{2}: \mathrm{pH}_{2} \mathrm{O}$ ratio is not expected to change dramatically, it is evident that even minor changes have an effect in the reduction process. The results are in agreement with previous TPR studies on $\mathrm{Ru} / \mathrm{Co} / \mathrm{Y}$ $\mathrm{Al}_{2} \mathrm{O}_{3}$ catalysts demonstrating that even with an inlet $\mathrm{pH}_{2}: \mathrm{pH}_{2} \mathrm{O}$ ratio of 8 an approximate delay of $5{ }^{\circ} \mathrm{C}$ and $65{ }^{\circ} \mathrm{C}$ in the temperatures of the maximum $\mathrm{H}_{2}$ consumption rates was observed $^{8}$.

The loss of active metal due to strong interaction with the $\gamma$ $\mathrm{Al}_{2} \mathrm{O}_{3}$ support has been a topic of scientific interest for many years. It has been proposed that the formation of mixed cobaltsupport oxide phases takes place during calcination ${ }^{16-18}$, reduction $^{7,8,33}$ and at reaction condition ${ }^{14,34,35}$. Although the high temperature chemistry of this solid-state reaction resulting in the crystalline spinel $\mathrm{CoAl}_{2} \mathrm{O}_{4}$ rich in $\mathrm{Co}^{2+} \mathrm{T}_{d}$ is reasonably known, the formation of the non-stoichiometric surface compound that lacks long range order is difficult to be detected. Here we take advantage of the global information that is obtained from synchrotron $\mathrm{X}$-ray diffraction patterns that contains both the changes in the state of the catalytically active compound as well as the support. The expansion of the unit cell of the $\gamma-\mathrm{Al}_{2} \mathrm{O}_{3}$ support is an indirect evidence of the partial diffusion of $\mathrm{Co}^{2+}$ that takes place during the first step of the reduction process and simultaneously with the formation of $\mathrm{Co}^{2+} \mathrm{O}_{\mathrm{h}}$. The Co-support interaction has been captured in situ. It has also been demonstrated that the overall reduction process is inhibited by the $\mathrm{H}_{2} \mathrm{O}_{(\mathrm{g})}$ generated in situ during the process. The implications of the founding can be used towards optimization of reduction kinetics for the formation of a catalyst with balance between performance (high degree of reduction) and better stability (sintering prevention, due to increased metal-support interactions) ${ }^{36}$.

This work forms a part of the inGAP (Innovative Natural Gas Processes and Products) Centre of Research-based Innovation, which receives financial support from The Research Council of Norway under Contract No. 174893. The authors would like to thank The Research Council of Norway and Statoil for financial support through the inGAP project. Dmitry Chernyshov (SNBL- 
BM01A) together with Alexey Voronov (NTNU) and David Wragg (UiO), are acknowledged for experimental assistance in the beam-time. ESRF beamtime 01-02-923 SNBL-BM01A and 01-01-853 SNBL-BM01B.

\section{Notes and references}

1 B. Delmon, Handbook of Heterogeneous Catalysis, Wiley-VCH Verlag GmbH \& Co. KGaA, Weinheim, Germany, 2008.

2 B. M. Vogelaar, a. D. van Langeveld, P. J. Kooyman, C. M. Lok, R. L. C. Bonné and J. A. Moulijn, Catal. Today, 2011, 163, 20-26.

3 B. M. Weckhuysen, Chem. Commun. (Camb)., 2002, 97-110.

4 M. E. Dry, Catal. Today, 2002, 71, 227-241.

5 E. Rytter, N. Tsakoumis and A. Holmen, Catal. Today, 2015.

6 N. E. Tsakoumis, M. Rønning, $\varnothing$. Borg, E. Rytter and A. Holmen, Catal. Today, 2010, 154, 162-182.

7 A. M. Hilmen, D. Schanke and A. Holmen, Catal. Letters, 1996, 38, 143-147.

8 Y. Zhang, D. Wei, S. Hammache and J. G. Goodwin, J. Catal., 1999, 290, 281-290.

9 A. Sirijaruphan, A. Horváth, J. G. Goodwin and R. Oukaci, Catal. Letters, 2003, 91, 89-94.

10 M. Rønning, N. E. Tsakoumis, A. Voronov, R. E. Johnsen, P. Norby, W. van Beek, $\varnothing$. Borg, E. Rytter and A. Holmen, Catal. Today, 2010, 155, 289-295.

11 D. G. Castner, P. R. Watson and I. Y. Chan, J. Phys. Chem., 1990, 94, 819-828.

$12 \varnothing$. Borg, M. Rønning, S. Storsæter, W. van Beek, A. Holmen, W. van Beek and A. Holmen, Stud. Surf. Sci. Catal., 2007, 163, 255271.

13 G. Jacobs, Y. Ji, B. H. Davis, D. Cronauer, A. J. Kropf and C. L. Marshall, Appl. Catal. A Gen., 2007, 333, 177-191.

14 N. E. Tsakoumis, A. Voronov, M. Rønning, W. van Beek, $\varnothing$. Borg, E. Rytter and A. Holmen, J. Catal., 2012, 291, 138-148.

15 R. Dehghan, T. W. Hansen, J. B. Wagner, A. Holmen, E. Rytter, $\varnothing$. Borg and J. C. Walmsley, Catal. Letters, 2011, 141, 754-761.

16 P. Arnoldy and J. A. Moulijn, J. Catal., 1985, 93, 38-54.

17 R. L. Chin and D. M. Hercules, J. Phys. Chem., 1982, 86, 360-367.

18 G. Jacobs, T. K. Das, Y. Zhang, J. Li, G. Racoillet and B. H. Davis, Appl. Catal. A Gen., 2002, 233, 263-281.

19 B. Jongsomjit, J. Panpranot and J. G. Goodwin, J. Catal., 2001, 204, 98-109.

20 A. Moen, D. G. Nicholson, B. S. Clausen, P. L. Hansen, A. M. Molenbroek and G. Steffensen, Chem. Mater., 1997, 9, 12411247.

21 D. J. Moodley, A. M. Saib, J. van de Loosdrecht, C. A. WelkerNieuwoudt, B. H. Sigwebela and J. W. (Hans) Niemantsverdriet, Catal. Today, 2011, 171, 192-200.

22 W. van Beek, O. V. Safonova, G. Wiker and H. Emerich, Phase Transitions, 2011, 84, 726-732.

23 B. S. Clausen, G. Steffensen, B. Fabius, J. Villadsen, R. Feidenhans'I and H. Topsøe, J. Catal., 1991, 132, 524-535.

24 J. W. Couves, J. M. Thomas, D. Waller, R. H. Jones, A. J. Dent, G. E. Derbyshire and G. N. Greaves, Nature, 1991, 354, 465-468.

25 A. P. Hammersley, S. O. Svensson, M. Hanfland, A. N. Fitch and D. Hausermann, High Press. Res., 1996.

26 A. Coelho, 2008, Topas V4.2 (Bruker AXS), Karlsruhe, Germany.

27 M. Wojdyr, J. Appl. Crystallogr., 2010, 43, 1126-1128.

28 N. E. Tsakoumis, R. Dehghan, R. E. Johnsen, A. Voronov, W. van Beek, J. C. Walmsley, $\varnothing$. Borg, E. Rytter, D. Chen, M. Rønning and A. Holmen, Catal. Today, 2013, 205, 86-93.
29 W. Kollenberg and J. Margalit, J. Mater. Sci. Lett., 1992, 11, $991-$ 993.

30 P. H. Bolt, F. H. P. M. . H. P. M. Habraken and J. W. W. Geus, J. Solid State Chem., 1998, 135, 59-69.

31 A. S. Andreev, J.-B. d'Espinose de Lacaillerie, O. B. Lapina and A. Gerashenko, Phys. Chem. Chem. Phys., 2015, 17, 14598-14604.

32 O. Madelung, Semiconductors: data handbook, Springer, 2004.

33 A. Moen, D. G. Nicholson, B. S. Clausen, P. L. Hansen, A. Molenbroek and G. Steffensen, Chem. Mater., 1997, 4756, 1241-1247.

34 D. J. Moodley, A. M. Saib, J. Van De Loosdrecht, C. a. WelkerNieuwoudt, B. H. Sigwebela and J. W. (Hans) Niemantsverdriet, Catal. Today, 2011, 171, 192-200.

35 G. Jacobs, P. M. Patterson, T. K. Das, M. Luo and B. H. Davis, Appl. Catal. A Gen., 2004, 270, 65-76.

36 J. A. Farmer and C. T. Campbell, Science (80-. )., 2010, 329, 933936. 